\author{
Radosław Kupczyk \\ Uniwersytet Wrocławski \\ e-mail: radoslaw.kupczyk@uwr.edu.pl
}

\title{
PROBLEM KOORDYNACJI POLITYKI GOSPODARCZEJ W UNII EUROPEJSKIEJ
}

\section{THE PROBLEM OF ECONOMIC POLICY COORDINATION IN THE EUROPEAN UNION}

DOI: $10.15611 / \mathrm{pn} .2018 .539 .11$

JEL Classification: H11

Streszczenie: Głównym problemem związanym z przeciwdziałaniem skutkom kryzysu gospodarczego w Unii Europejskiej okazał się brak możliwości wykorzystania instrumentów polityki gospodarczej na poziomie ponadnarodowym. Celem artykułu jest zbadanie, w jaki sposób wprowadzone zmiany w zakresie zarządzania gospodarczego wpłyną na efektywność prowadzonej polityki gospodarczej na poziomie ponadnarodowym. W pierwszej części przedstawiono problemy związane z zacieśnieniem dyscypliny finansowej jako podstawowej metody zarządzania w Unii Europejskiej. Przeanalizowano również wpływ reform dotyczących zarządzania gospodarczego na politykę społeczną na poziomie krajowym. W części drugiej zbadano propozycje zmian instytucjonalnych wpływających na polepszenie koordynacji polityki gospodarczej w ramach nadzoru nad polityką fiskalną. Do realizacji postawionych w artykule celów wykorzystano teorię optymalnej kontroli oraz analizę systemową.

Słowa kluczowe: polityka gospodarcza, zarządzanie gospodarcze, semestr europejski.

Summary: The main problem related to counteracting the effects of the economic crisis in the European Union was the inability to use the measures of economic policy at the supranational level. The aim of the article is to examine how the changes introduced in the field of economic governance will affect the effectiveness of the economic policy pursued at the supranational level. The first part presents problems related to tightening financial discipline as the basic method of management in the European Union. The impact of reforms on economic governance on social policy at the national level was also analyzed. The second part examines the proposals of institutional changes affecting the improvement of economic policy coordination within the framework of supervision over fiscal policy. The optimal control theory and the system analysis were used to achieve the goals set in the paper.

Keywords: economic policy, economic governance, European semester. 


\section{Wstęp}

Polityki gospodarczej nie można analizować w oderwaniu od uwarunkowań politycznych, ponieważ obie te kategorie są współzależne i wzajemnie uzupełniając się, tworzą system społeczno-ekonomiczny [Eucken 2005, s. 386]. Wskazuje się, że rozwiązanie problemów gospodarczych Unii Europejskiej powinno odbywać się poprzez pogłębianie procesów integracyjnych [Grosse 2010]. Jednak realizacja tego celu wymaga przekonania obywateli państw członkowskich, a zwłaszcza ich rządów, do akceptacji dalszego ograniczania suwerenności w zakresie prowadzonej polityki gospodarczej. W związku z tym należy zastanowić się, w jaki sposób można przeciwdziałać występowaniu nierównowag zagrażających spójności i stabilności gospodarek państw członkowskich UE. Trwała poprawa obecnego systemu koordynacji polityki powinna być priorytetem na najbliższe lata i winna wiązać się ze zmianami instytucjonalnymi i traktatowymi.

Jedną z teorii, odnoszącą się do problematyki funkcjonowania Unii Gospodarczej i Walutowej, jest teoria optymalnej kontroli. Jest to koncepcja sformułowana w 1988 roku przez dwóch badaczy, Francesca Giavazziego i Marca Pagana, którzy przeanalizowali powody przystąpienia Włoch do Europejskiego Mechanizmu Kursowego [Giavazzi, Pagano 1998]. Autorzy odwołali się w swych badaniach do prac Finna Kydlanda i Edwarda Prescotta [Kydland, Prescott 1997], laureatów Nagrody Nobla, oraz prac Roberta Barra i Davida Gordona [Barro, Gordon 1983], adaptując je do uwarunkowań i specyfiki europejskiego procesu integracji walutowej.

Teoria optymalnej kontroli prezentuje koncepcję funkcjonowania polityki gospodarczej UGW, obligującą państwa do dbania zarówno o stabilność cen, jak i finansów publicznych w ramach ponadnarodowego zarządzania gospodarkami, nawet jeśli wcześniej stabilności tej nie potrafiły zapewnić. Z punktu widzenia prezentowanej teorii zobowiązania takie opierają się na dobrowolności i samokontroli, ponieważ w świecie, w którym wyborcy znają preferencje i ograniczenia rządu, administracja rządowa nie może dopuszczać do powstawania kryzysu zadłużeniowego [Giavazzi, Pagano 1998].

Doświadczenia nabyte zarówno przed, jak i po wybuchu kryzysu gospodarczego wskazują, że kontrolowanie tylko wymiaru fiskalnego polityki gospodarczej w zakresie dyscypliny budżetowej jest niewystarczające. Jeśli państwa członkowskie UE chcą ograniczyć negatywne konsekwencje spekulacji rynkowych, dotyczące kryzysu zadłużeniowego, muszą zwiększyć zakres konwergencji fiskalnej w celu poprawy procesów dostosowawczych. Szczególnie istotna jest kwestia monitorowania wzrostu płac w sferze budżetowej i wydatków na politykę społeczną. W odniesieniu do systemu instytucjonalnego zwraca się uwagę na opracowanie ponadnarodowych instrumentów możliwych do wykorzystania w sytuacjach kryzysowych. Należy jednak podkreślić, że dalsze pogłębienie integracji wymagałoby ponownego doprecyzowania koncepcji wspólnej polityki gospodarczej. Jest to szczególnie istotne w kontekście wypracowania mechanizmów pozwalających na szybkie przeciw- 
działanie kryzysom gospodarczym wynikającym z prowadzenia nieodpowiedzialnej polityki fiskalnej przez państwa członkowskie UE.

\section{Problem zarządzania gospodarczego na szczeblu ponadnarodowym}

Kluczową kwestią skutecznego prowadzenia wspólnej polityki gospodarczej jest odpowiedź na pytanie, czy możliwa jest koordynacja ponadnarodowej polityki pieniężnej prowadzonej przez niezależny ponadnarodowy bank centralny, wspieranej przez rządy odpowiedzialne za prowadzenie polityki fiskalnej. Jest to o tyle ważne, że realizacja tych polityk ma na celu jednoczesne osiągnięcie stabilności cen oraz wzrostu gospodarczego. Od momentu powstania euro w 1999 roku, a nawet w okresie wcześniejszym badacze zwracali uwagę na problem unijnych mechanizmów koordynacji polityki gospodarczej [Giavazzi, Pagano 1998; Buiter, Corsetti, Roubini 1993; Hughes-Hallett, Mooslechner 1999]. Pakt stabilności i wzrostu jest konsekwentnie krytykowany przez ekonomistów jako nie w pełni przemyślany i co za tym idzie nieskuteczny zestaw zasad, prowadzący do procyklicznej polityki fiskalnej hamującej wzrost gospodarczy i zmniejszający długoterminowy potencjał gospodarczy nie tylko państw UGW, ale również pozostałych członków UE [Krugman 2012]. Wskazuje się również na inercję stworzonego systemu w zakresie spójności i elastyczności prowadzonych polityk gospodarczych na poziomie krajowym.

W reakcji na kryzys w strefie euro politycy postanowili zreformować podstawy instytucjonalne i poprawić je w zakresie zarządzania, ze szczególnym uwzględnieniem uprawnień do kontroli deficytów budżetowych. Stało się tak wbrew ekonomistom, którzy na podstawie teorii optymalnego obszaru walutowego wskazywali na centralizację polityki gospodarczej poprzez zastosowanie modelu federalnego opartego na wspólnym budżecie, ministerstwie finansów i innych ponadnarodowych instytucjach. Powstaje więc zasadnicze pytanie: jak w takich warunkach skutecznie koordynować politykę gospodarczą? Można wskazać na trzy podstawowe problemy związane z zarządzaniem gospodarczym w UE.

Po pierwsze, obecne podejście, oparte na zdecentralizowanym uniwersalizmie, nie bierze pod uwagę oddziaływania na zagregowany popyt i produkcję. Dążenie do ograniczania ekspansywnej polityki fiskalnej we wszystkich państwach członkowskich w tym samym czasie, choć z różną prędkością, utrwaliło procesy ograniczania wzrostu PKB. Wprowadzona procedura dotycząca zakłóceń równowagi makroekonomicznej przyczyniła się do wzrostu jednostkowych kosztów pracy, jednocześnie nie wprowadzając przy tym mechanizmów łagodzących to zjawisko. Istnieje natomiast powszechne przekonanie, że w wyniku wzrostu płac w gospodarce niemieckiej nastąpi pobudzenie popytu wewnętrznego w gospodarkach państw członkowskich UE, co może z kolei ułatwić procesy dostosowawcze. Jeżeli narzucone restrykcje fiskalne ograniczają wzrost gospodarczy, to zarządzanie gospodarcze, które przeja- 
wia się w prowadzonej polityce ekonomicznej powinno opierać się na ściślejszych ramach współpracy, uwzględniając przy tym wszystkie interesy i uwarunkowania gospodarek państw UE.

Po drugie, przyjęty model zarządzania gospodarczego w ramach prowadzonej polityki ekonomicznej opiera się na konwergencji wskaźników fiskalnych, w konsekwencji ograniczając możliwość wykorzystania ekspansywnej polityki fiskalnej w zakresie rozwoju gospodarki dobrobytu, rozwoju zrównoważonego, dążenia do spójności gospodarczej, społecznej i terytorialnej oraz przeciwdziałania ,,wykluczeniu społecznemu" (art. 3 Traktatu o Unii Europejskiej). W rezultacie wprowadzenie semestru europejskiego, mającego na celu koordynację polityki ekonomicznej, szczególnie w zakresie polityki fiskalnej, nie traktuje celów strategii Europa 2020 na równi z regułami fiskalnymi. Stwarza to zagrożenie w postaci polaryzacji gospodarek państw UE, co w perspektywie długoterminowej może utrudniać ich konwergencję [Zwierzchlewski 2015, s. 62]. Stagnacja w wydatkach na badania i rozwój, trudności w dostępie do kredytów, marnotrawstwo kapitału ludzkiego, a w konsekwencji wzrost ubóstwa w państwach południowej Europy utrudniają osiąganie wysokiego tempa rozwoju gospodarczego. Wzrost migracji siły roboczej związany z tymi zjawiskami jest symptomem zahamowania procesów konwergencji wewnątrz Unii Europejskiej.

Po trzecie, prowadzenie wspólnej polityki gospodarczej jest szczególnie trudne, ponieważ w bardzo dużym stopniu uzależnione jest od uwarunkowań i interesów politycznych poszczególnych państw członkowskich [Nowak-Far 2001]. Z kolei naciski instytucji ponadnarodowych na ograniczenie zakresu prowadzonych krajowych polityk ekonomicznych państw członkowskich może budzić sprzeciw i być kontestowane jako nieuprawnione odbieranie suwerenności w zakresie kompetencji zarządzania gospodarczego. Polityka wynagrodzeń i polityka społeczna są w coraz większym stopniu monitorowane poprzez instrumenty pośrednie związane z polityką fiskalną, co jest powszechnie postrzegane jako niezgodne z prawem unijnym zarówno w państwach wierzycieli, jak i dłużników. Można spotkać się również z poglądem, że jednolity rynek UE oraz Unia Gospodarcza i Walutowa znacznie ograniczają zdolność państw członkowskich do realizacji określonych przez siebie celów społeczno-gospodarczych [Ambroziak 2015]. Idea koordynacji polityki gospodarczej jest w najlepszym przypadku sposobem na optymalizację dostosowań celów polityki społecznej do uwarunkowań rynkowych i ograniczeń fiskalnych.

Dotychczasowe doświadczenia pokazują, że Komisja Europejska, próbując osiągnąć równowagę między trzema czynnikami: konsolidacją fiskalną, wzrostem gospodarczym i poziomem inwestycji, zaleca poszczególnym państwom członkowskim korektę nierównowagi fiskalnej i dążenie do osiągnięcia równowagi makroekonomicznej [Kraś 2016, s. 77]. Niemniej jednak państwa członkowskie mają znaczny margines swobody w opracowywaniu planów fiskalnych i programów reform. Należy zauważyć, że semestr europejski opiera się na dialogu, w którym prezentowane zalecenia nie są narzucane $\mathrm{z}$ góry do natychmiastowego wykonania, ale 
często negocjowane są z rządami krajowymi przez kilka miesięcy przy zaangażowaniu instytucji społecznych i parlamentów narodowych.

\section{Instrumenty kontroli polityki fiskalnej}

W reakcji na kryzys gospodarczy w strefie euro wprowadzono nowe instrumenty nadzoru fiskalnego. Pierwszym z nich jest roczny cykl procedury zakłóceń równowagi makroekonomicznej, który rozpoczyna się co roku publikacją Raportu ws. Mechanizmu Ostrzegania, opracowywanego przez Komisję Europejską dla gospodarek UE. Mechanizm ostrzegania wykorzystuje tablicę wyników wybranych wskaźników, aby skontrolować państwa członkowskie pod kątem potencjalnej nierównowagi gospodarczej wymagającej decyzji politycznych. Ocena opiera się również na innych istotnych wskaźnikach ekonomicznych, społecznych i finansowych nieuwzględnionych w głównej tablicy wyników. Na tej podstawie raport mechanizmu ostrzegania wskazuje na państwa, które wymagają dalszego nadzoru, ze szczególnym uwzględnieniem ryzyka makroekonomicznego. Pod koniec przeglądu Komisja Europejska ustala występowanie lub brak zakłóceń równowagi, a także określa ich zakres.

Wyniki tych badań stanowią część europejskiego semestru, który w ramach „pakietu zimowego”, jest publikowany w lutym wraz ze szczegółowym raportem krajowym dla każdego z państw członkowskich. W 2017 roku w ramach mechanizmu ostrzegania zidentyfikowano 13 państw (Bułgaria, Chorwacja, Cypr, Finlandia, Francja, Niemcy, Irlandia, Włochy, Holandia, Portugalia, Słowenia, Hiszpania i Szwecja), które wymagały pogłębionej analizy ekonomicznej i zostały ocenione pod kątem wzrostu gospodarczego oraz zagrożeń wynikających z braku równowagi makroekonomicznej [2017 European Semester: Alert Mechanism Report].

Drugim instrumentem wykorzystywanym w ramach semestru europejskiego jest nadzór nad finansami publicznymi, realizowany zgodnie z zasadami Paktu stabilności i wzrostu poprzez część zapobiegawczą lub naprawczą, która jest w znacznej mierze związana ze stosowaną procedurą nadmiernego deficytu. Oprócz celów dotyczących deficytu, zgodnie z traktatami oraz obowiązującym prawodawstwem, stosunek długu publicznego do PKB powinien zbliżać się do wartości referencyjnej w zadowalającym tempie. Dług uznaje się za wystarczająco zredukowany, jeśli w ciągu trzech poprzednich lat dystans między wskaźnikiem długu a wartością odniesienia zmniejszał się średnio w tempie jednej dwudziestej rocznie, na podstawie zmian w trzech ostatnich latach, za które dostępne są dane. W 2017 roku procedurę uchylono wobec Chorwacji [Council Decision 2014/56/EU], Grecji [Council Decision 2009/415/EC] i Portugalii [Council 2010/288/EU]. Obecnie postępowanie w tym zakresie prowadzone jest jeszcze wobec 3 państw, tzn. Francji, Wielkiej Brytanii i Hiszpanii [Excessive deficit procedures - overview].

W ramach cyklu semestru europejskiego w 2017 roku zastosowano nowy instrument finansów publicznych w postaci komunikatu Komisji Europejskiej dotyczącego pozytywnego kursu polityki budżetowej w strefie euro [Komunikat Komisji]. 
Dokument ten został przyjęty wraz z zaleceniami dotyczącymi polityki gospodarczej prowadzonej w strefie euro w latach 2017-2018. Doprowadził on do dyskusji nad priorytetami gospodarczymi i społecznymi na poziomie UE, strefy euro i poziomie krajowym. Znalazło to odzwierciedlenie w polityce państw członkowskich, a zwłaszcza w krajowych programach gospodarczych. Nie rozwiązuje to jednak problemu braku instrumentów fiskalnych pełniących funkcję stabilizacyjną nie tylko na poziomie UE, ale również na poziomie strefy euro, co zapewniłoby zrównoważenie gospodarek wszystkich państw członkowskich.

Trzecia kategoria narzędzi nadzoru europejskiego semestru dotyczy strategii Europa 2020, strategii UE na rzecz inteligentnego, trwałego wzrostu gospodarczego, sprzyjającego włączeniu społecznemu. Składa się z zestawu celów, które ma osiągnąć nie tylko UE jako całość, ale również każde państwo członkowskie, zmierzających do poprawy konkurencyjności przy jednoczesnym zachowaniu modelu społecznej gospodarki rynkowej oraz znacznej poprawie efektywności wykorzystania zasobów. Każde państwo członkowskie ustala własne priorytety krajowe, które należy zrealizować do 2020 roku, a wyniki można łatwo zmierzyć zarówno na poziomie krajowym, jak i europejskim. Cele pozostają politycznie wiążące i są nieodłącznym elementem każdego semestru europejskiego w zakresie ewaluacji. Stanowią one podstawę polityki w obszarach zatrudnienia, wydatków na badania i rozwój, redukcji emisji gazów cieplarnianych, włączenia społecznego i edukacji.

\section{Zakończenie}

Po kryzysie gospodarczym, związanym z utratą stabilności finansów publicznych niektórych państw strefy euro, UE wzmocniła zarządzanie gospodarcze poprzez poprawę koordynacji polityki gospodarczej i wykorzystanie instrumentów europejskiego semestru, takich jak rekomendacje krajowe. Chociaż Komisja Europejska pozostaje odpowiedzialna za wiele narzędzi i dokumentów europejskiego semestru, to państwa członkowskie UE mają zasadniczy wpływ na proces tworzenia i wdrażania reform i budżetów krajowych. Unia Europejska w ramach polityki gospodarczej zapewnia tworzenie wytycznych i pomocy dla państw, które nie osiągają wyznaczonych celów.

Unia Europejska stoi dziś przed wieloma wyzwaniami. Europejski semestr dotyczy nie tylko problemów gospodarczych, ale również tworzy mechanizmy i narzędzia nadzoru i koordynacji kwestii politycznych. W tym kontekście szczególnie ważne jest, aby pamiętać, że interesy i uwarunkowania krajowe należy uwzględniać we wszystkich obszarach kształtowania polityki gospodarczej, zmierzającej do zapewnienia nie tylko wzrostu gospodarczego, ale i rozwoju wszystkich państw członkowskich.

Ściślejsza koordynacja polityk gospodarczych i społecznych wydaje się jedyną możliwą opcją dla państw członkowskich, które chcą utrzymać wspólną walutę, ale niechętnie przekazują instytucjom UE środki fiskalne i część suwerenności. W takim 
przypadku należy wprowadzić bardziej jakościowe i skuteczne mechanizmy konwergencji w UE. Poza ścisłym przestrzeganiem zasad i wąską interpretacją unijnych ram prawnych przywódcy polityczni mogą wykorzystać więcej możliwości, jakie otwierają traktaty. Zwolennicy szerszych wysiłków na rzecz konwergencji zgodnie z ambitną wizją strategii Europa 2020 powinni zaproponować wzmocnienie dialogu społecznego na poziomie UE i nadzorowanie nierówności społecznych w trakcie europejskiego semestru.

Wybór metod koordynacji nie powinien jednak być nadmiernie eksponowany, ponieważ to przyczyny polityczne mają wpływ na stabilizację gospodarczą. Pod względem ekonomicznym różnorodność modeli krajowych i strategii konkurencyjności bardzo utrudnia państwom członkowskim uzgodnienie wspólnych priorytetów w ramach europejskiej polityki gospodarczej. Polityka koordynacji wymaga wzbogaconego dialogu, zarówno na poziomie wertykalnym - pomiędzy instytucjami unijnymi i krajowymi, jak i na poziomie horyzontalnym - wśród przywódców państw członkowskich.

\section{Literatura}

2017 European Semester: Alert Mechanism Report, https://ec.europa.eu/info/publications/2017-european-semester-alert-mechanism-report_en_(26.03.2018).

Ambroziak A.A., 2015, Reindustrialization and servitization: trade tendencies in the European Union internal market, [w:] Małuszyńska E., Mazur G., Idczak P. (red.), Unia Europejska wobec wyzwań przyszłości. Aspekty prawne, finansowe $i$ handlowe, Wydawnictwo Uniwersytetu Ekonomicznego w Poznaniu, Poznań.

Barro R., Gordon D.B., 1983, A positive theory of monetary policy in a natural rate model, Journal of Political Economy, 91(4), s. 589-610.

Buiter W.H., Corsetti G., Roubini N., 1993, Excessive deficits: sense and nonsense in the Treaty of Maastricht, Economic Policy, 16, s. 57-100.

Council Decision abrogating Decision 2009/415/EC on the existence of an excessive deficit in Greece, https://ec.europa.eu/info/sites/info/files/com_2017_380_en.pdf (26.03.2018).

Council Decision abrogating Decision 2010/288/EU on the existence of an excessive deficit in Portugal, http://eur-lex.europa.eu/legal-content/EN/TXT/PDF/?uri=CELEX:32017D1225\&from=EN (26.03.2018).

Council Decision abrogating Decision 2014/56/EU on the existence of an excessive deficit in Croatia, https://ec.europa.eu/info/sites/info/files/2017-06-16_hr_126-12_council_en.pdf (26.03.2018).

Eucken W., 2005, Podstawy polityki gospodarczej, Wydawnictwo Poznańskie, Poznań.

Excessive deficit procedures - overview, https://ec.europa.eu/info/business-economy-euro/economic-and-fiscal-policy-coordination/eu-economic-governance-monitoring-prevention-correction/ stability-and-growth-pact/corrective-arm-excessive-deficit-procedure/excessive-deficit-procedures-overview_en (26.03.2018).

Giavazzi F., Pagano M., 1998, The advantage of tying one's hands: EMS discipline and Central Bank Credibility, European Economic Review, 32, s. 1055-1082.

Grosse T.G., 2010, Systemowe uwarunkowania kryzysu strefy euro, http://www.bibliotekacyfrowa.pl/ Content/35518/015.pdf (26.03.2018). 
Hughes-Hallett A., Mooslechner P., 1999, Challenges for economic policy coordination within European Monetary Union, Special issue of Empirica, 26(3).

Komunikat Komisji do Parlamentu Europejskiego, Rady, Europejskiego Banku Centralnego, Europejskiego Komitetu Ekonomiczno-Społecznego i Komitetu Regionów w kierunku pozytywnego kursu polityki budżetowej w strefie euro, http://eur-lex.europa.eu/resource.html?uri=cellar: 30353466-b172-11e6-871e-01aa75ed71a1.0021.02/DOC_1\&format=PDF (26.03.2018).

Kraś I., 2016, Rozwiązania instytucjonalne w polityce makroostrożnościowej Unii Europejskiej, [w:] Kraś I. (red.), Zarzadzanie gospodarcze Unii Europejskiej w drugiej dekadzie XXI wieku, Difin, Warszawa.

Krugman P., 2012, Europe's Economic Suicide, https://www.nytimes.com/2012/04/16/opinion/krugman-europes-economic-suicide.html (26.03.2018).

Kydland F.E., Prescott E.C., 1997, Rules rather than discretion: The inconsistency of optimal plans, Journal of Political Economy, 85(3), s. 473-491.

Nowak-Far A., 2001, Unia Gospodarcza i Walutowa w Europie, Wydawnictwo C.H. Beck, Warszawa.

Zwierzchlewski S., 2015, Stabilność unii walutowej, Adam Marszałek, Toruń. 